\title{
Multinational Corporation and Foreign Direct Investment: An Implication for Third World States
}

\author{
Mohammed Ghani Dass ${ }^{1 *}$ and Abdulmajid Jamal ${ }^{2}$ \\ ${ }^{1}$ School of Environmental Technology, Abubakar Tafawa Balewa University, IJMB, Jos Road, Wuntin Dada, Bauchi, Nigeria \\ ${ }^{2}$ School of General Studies, Abubakar Tatari Ali Polytechnic, Bauchi, Nigeria
}

\begin{abstract}
Multinational Corporations and Foreign Direct Investment has been identified as agents of underdevelopment and dependency of the less develop countries, in a quest to achieve their economic motives. The institution also served as a tool in influencing the political power of the host countries, under development and dependency, theory is employed to guide the analysis of this work. The theory hinges on the fact that the multi-national corporations plays strategic role in determining production, accumulations, exploitation and politics of the world and the less develop countries in particular. The theory further explains slaves trade, colonialism and imperialism was responsible for the under development of the third world states. Content analysis is employed as a source of data collection and its revealed that the multi-national corporation/FDI are agents of both growth and underdevelopment of the host countries. The paper critically reviewed the existing literature both conceptually, empirically and thematically and relied on secondary sources of data and examination of official documents as its methodology. The paper is structured into six interrelated compartments. Also in the recommendations the role of MNCS and FDI should be inconsonant with the host country's home grown policies and not policies from without. The major findings has it that the over reliance on the monocultural production such as oil, by the host countries is responsible for the dominant of the periphery's economy by the multinational corporations and foreign direct investment. This is in addition to lack of political will in the part of the leaders/governments of the host countries. The paper concludes or rather recommends that the less develop countries should diversity massively to agriculture, and other sources, as an alternative to oil and other monoculture source. This is in additions to high level of exportation to international markets. Full fledge political will in the part of the host countries should be encouraged. Least or short of the above suggestions the issues raised will remain unresolved.
\end{abstract}

Keywords: Multi-national corporation; Foreign direct investment; Third-world

\section{Introduction}

Multinational corporation: this is a business organization whose activities are located in more than one or two countries, it represent both economic motives of its owners as well as serving as organizational mechanism by which different social and political systems confront themselves. As a large and rapidly expanding sector of the world economy is equally characterized by a revolutionary new system of production and accumulation in a world scale. Third world: less develop states are contemporary referred to as the third world, in the international economic relation, or rather new world order. These states are categorized by the world economic powers to maintain the centre and periphery relations. In other words, to maintain the capitalist exploitation. These states include Africa, Asia and the Latin America. The two concepts, Multinational Corporations (MNCS) and Foreign Direct Investment (FDI) are interrelated intertwined and in an actual sense they go hand in hand. In other words, there exist an umbilical cord relationship between MNCS and FDI simply because in specific and numeric terms, MNCS account for 9520 of total world' FDI. Aja [1] noted that: Foreign Direct Investment is facilitated primarily by MNCS that commands the monopoly of world capital, technology and market ideology MNCS facilitate the flows of capital and technology across national boundaries by adopting entry strategies corporate strategies, optional timing, strategic location behaviour, trade creation and market service strategies. It should be noted for clarify that workers and element of technical knowledge also move with the flow investment capital beyond national boundaries. These flows substantially affect the product of goods and services, employment opportunities, and the distribution of output in the various part of the world [2]. FDI is generally an integral part of the global corporate strategy for MNCS operation in oligopolies market. FDI creates economic relations of an integrative nature and involve the cooperation in the international affairs of a country. This process is however too controversial in terms of socio-economic impacts on the host countries. The point is that foreign production has become a vital component in the integration of global strategies of MNCS that now dominates international economy [1].

The origin of both MNCS and FDI dates back to the $19^{\text {th }}$ century when industrial firms of Britain, France, Germany, Italy, Belgium and lately Japan, United States of America etc. scrambled for raw material in Africa, Latin America and Asia. They were supported by their national government to invest capital in the vast non-industrial territories. This paper will therefore examine the history, characteristics, argument for and MNCS/FDI particularly as its relate to less develop countries (LDCs) like Nigeria.

\section{Conceptual clarification}

Foreign direct investment: In the word of Aja [1], foreign direct Investment can be described as: "an investment behavior when an individual or industrial firm has expanded asset resource resources

*Corresponding author: Mohammed Ghani Dass, School of Environmental Technology, Abubakar Tafawa Balewa University, IJMB, Jos Road, Wuntin Dada, Bauchi, Nigeria, Tel: +234-08088525991; E-mail: abufatima25@yahoo.com

Received July 20, 2018; Accepted August 11, 2018; Published August 18, 2018

Citation: Dass MG, Jamal A (2018) Multinational Corporation and Foreign Direct Investment: An Implication for Third World States. Arts Social Sci J 9: 393. doi: 10.4172/2151-6200.1000393

Copyright: ( 2018 Dass MG, et al. This is an open-access article distributed unde the terms of the Creative Commons Attribution License, which permits unrestricted use, distribution, and reproduction in any medium, provided the original author and source are credited. 
from one country to the other in compliance with the legislation of the host country.

Multinational corporation (MNCs): Spero [2] sees the term multinational corporation as "a firm with foreign subsidiaries which extend the production and marketing of the firm beyond the boundaries of any country. They are firms which sent abroad a package of capital, technology, managing talent and marketing skill to carryout production in foreign country. Eldrige [3] in his part opined that MNC connotes business concerns with operations in more than one country in which the operations outside the company's home country may be linked to the parent by merger, operated as subsidiaries or have considerable autonomy. Judging from the above MNCs and FDI are seen as international centered with sole motive of promoting the economic interest of her mother country. And in the process, they constitute a hegemonic control of the political economy of the periphery states.

\section{Literature Review}

\section{History of MNCs and FDI}

History has it that, the origin of modern MNCs/FDI dates back to Europe's great trading companies. It started prominently with Dutch East India Trading company in the $19^{\text {th }}$ century Industrial Revolution and Capitalism in Europe, the exports of capital and production technology to pre-industrial territories of Africa, Asia and Latin America were championed by the biggest industrial powers, notably Britain, France, Germany and Italy. In the early $20^{\text {th }}$ century the United States sought one competition of the European economy in the export of production technology and foreign investment [1]. Subsequently, the corporations of the U.S, Japan and the European States increased fierce criss-crossing FDI strategies America's increased her investment venture in Western Europe. American FDI in petroleum sector increased in the Middle East and other oil export countries, including Nigeria. FDI "is a way of penetrating and establishing control over another social unit by means of capital export. It usually takes the form of establishing a wholly owned subsidiary firm, the large MNCs obviously being the investors in other words, FDI is a mechanism used by the corporation to penetrate foreign market and obtain their resources [4].

The MNCs are interested in less Developed Countries (LDCs). For instance, official source have noted that American Companies invested well over 87 billion in Nigeria's Petroleum Sector. The USA has described Nigeria as one of the four priority counties in the world along with Columbia Ukraine and Indonesia. In the mould of former America's president (Clinton) message to Nigeria through the Secretary of State, M. Albright and Treasury Secretary Rubin, maintains that: We are interested in Nigeria because the stakes are so high. A democratic Nigeria is a key to a stable and prosperous West Africa an invigorated Africa and to U.S national and economic security. Nigeria is our good largest trading partner in all Africa [1]. MNCs are growing from strength to strength on regular basis. They have spread their tentacles to the entire nooks and crannies of the world and to virtually all aspects of human endeavour. Eldridge [3] noted' there are over 40,0900 MNCs currently operating in the global economy, overseas affiliates running crossed 250,000 continental business. In 1995, the top 200 MNCs had combined sales of 87.1 trillion, which is equivalent to 28.37 .8 the world GMP. The top MNCs are headquartered in the U.S, Western Europe and Japan: they have the capacity to shape global trade, production and financial transaction.

\section{Theoretical frame work}

It is always imperative in social science discourse or research to use theory in order to guide the analysis of the work. This paper adopts under development and dependency theory (UDT) in explaining the activities of MNCs and FDI. The proponents of the theory includes Walter Rodney, Samir Amin, Gundar Frank, Galtung Johan, Immanuel Wallestain among others. The thrust of the under development and dependency theory focused on the believed that "The modern world system are informative enough that under development was not a natural phenomena but a dependency structure created by the activities of MNCs through the support of their parent country".

The strengths of the theory is that it has exposed or rather unveil the evil nature of the contemporary imperialism on the periphery states, and encourage local production by the Africa, Asia and the Latin American sphere.

The weaknesses of the theory is that there is no clear cut solution to delink the umbilical cord relationship with the exploiting states and the institutions such as the U.S.A, Japan, Britain as well as the MNCs and the FDI respectively.

Buttressing the above Pricisms, as well as contemporary relevance of the theory (underdevelopment and dependency) on the less development countries (LDCs) noted that of the 823 trillion global GDP in 1993, \$18 trillion is in the industrial states, only $\$ 5$ trillion in the developing countries, even though they have nearly $80 \%$ of the world's people.

Analysing Tando's submission on the economic exploitation by the industrial states the data provided will equally guide our analysis on the cantankerous activities of the MNCs/FDI. It is evident that MNCs used the less Develop states as a conduit pipe to drain its resources to their parent country and rendered them (LDC) in abject and continuous poverty with high rate of environmental degradation. About $77 \%$ of the world population lives in the south, yet they produce only $15 \%$ of the Gross National Product (GNP). The $23 \%$ of the people who are geographically fortunate to reside in the north, command $85 \%$ of the world's wealth $[5,6]$.

The underdevelopment and Dependency theory maintained that, the MNCs plays strategic role in determining production accumulation, exploitation and politics' of the world. Daniel Offiong noted explicitly that the further concentration and centralization of capital and the integration of the world capitalist economy into the structures of the giant United States based MNC or integrated conglomerate monopolistic enterprises and acceleration of technological change was done under the auspices of these corporations [7]. The active participation of capital in the international investment and global foreign policy which correspond to the global interest and perspective of MNCs. It is also argued in different quarters that development can come through the MNCs mechanism particularly in transferring technology capital and skills in management design and marketing. However the underdevelopment theory debunked that, the current form and penetration of foreign monopoly capital in developing countries is the major cause of their under development and dependency. This can be attested to the issue of share trade, colonialism and imperialism where Rodney stressed that Africans went to colonialism with "hoe" and returned home with "hoe"!

In summary, also as relevance of the theory to the contemporary activities of the MNCs on the less Development states (LDC), shows that the lop-sided nature of the international economic system, the 
LDCs are "calling for a paradigm shift or better still a new world international economic order (NIECO) through right to development, disbarment and economic cooperation, this is due to incessant control and command that MNCs and other international financial institutions have exercise over the third world economics. As a matter of fact, policies in most third world states is not home grown and autonomous, they are initiated from without, package and monitored by the west, and USA served as captain.

\section{Characteristics of MNCs}

Paraphrasing Aja [1], highlighted the following as the unique features of MNCs.

The ownership of MNCs is private monopoly corporations. MNCs are not government-to-government established, serviced and managed. MNCs are a non-governmental organization but through their activities, they had tremendous influence on both parent and host countries.

The decision making in MNCs tends to be more centralized. Policy control originates from the parent country and flows through subsidiaries and affiliates. MNCs have a large pool of management talent financial assets and technical resources, and they run their gigantic corporations with a co-ordinate global strategy.

As we have noted earlier on, MNCs are facilitiators of FDI. FDI creates economic relations of an integrative nature and involves the corporation in the internal affairs of a country. This process is, however, too controversial interms of socio-economic impacts on the host countries. The point is that foreign production has become a vital components in the international economy.

Technology Transfer is another feature of MNCs. They invest a lot in order to command the monopoly of technology. They also invest colossal sum in research and development processes. Given their global interconnectedness, MNCs are known to be facilitators of technology transfer, through joint ventures, patent rights, technical training, and development, and FDI. Transfer of technology remains controversial, yet the technology value of MNCs to any country depends on the existence of an indigenous (well functioning) technology base to interact and stimulate foreign technologies.

Although, MNCs do not force themselves on countries. Locally, they are empowered by the parent governments in both policy frame and by creating the enabling environment for productive ventures. Internationally MNCs are empowered or allowed entry by the nature of national legislations on foreign economic and other interests, and as sources of foreign wealth for their countries.

\section{Arguments in favor of MNCs/FDI}

This segment shall dwell on the benefits derives from MNCs/FDI, otherwise known $s$ the argument in favour of the MNCs/FDI, in their activities in the host states.

The activities of the MNCs as agents of development have generated controversies among scholars: Aja (2001:73-75) noted that:

MNCs have been known to have created considerable job or employment opportunities even in the developed and under developed countries. For instance, the reason why the U.S government is giving bailout package to "big" companies like General motors', is because of employment. In Nigeria MNCs have generated both skilled and unskilled jobs.
It has been argued in different quarters that MNCS, by virtue of job creation, have invariably trained, and occasionally transfer technology to host countries. Although it is controversial but yet, it will be unfair to deny absolutely that MNCs do not in some little way transfer skill and expertise to the host countries. Malaysia, India, Brazil and Argentina have well-functioning to absorb foreign technology.

Economic development takes off from joint ventures between host and MNCs activities in the host countries. For instance, in Nigeria an effort is being made by India to give operational life to Nigeria's largest iron and steel complex in Ajaokuta.

MNCs are not completely in different to the creation of good relationship not only with the host countries but also at their operationally based communities. For instance, one will not denied the fact that MNCs operating in Nigeria have built schools, libraries, hospitals pipe-borne water, access roads, health care services in local communities of their operations, i.e. corporate social responsibility.

The global out reach of MNCs creates and maintains global economic interdependence among nations'. For instance, in 1993 record has it that Japan had a total of 16.9 billion dollar investment in the USA, while the USA on its part had a total of 53.4 billion dollars investment in Japan. So, now economic interdependence means that Japan and US would not hastily enter into a state of war because of mutual economic interdependence which brings about more collaborative tendencies than tension.

\section{Arguments against MNCs/FDI}

This section will examine the views that MNCs are "agents" of underdevelopment. Marxists and UDT scholars have taken the lead in describing MNCs as instrument of the imperialist world, for deepening and expanding underdevelopment, particularly in the periphery. The arguments according to Aja (2011:76-78) are as follows:

It has been argued that MNCs do not really constitute facilitators of transfer of technology because they are very jealous of their technology as an instrument of reproducing capital and global economic influence. So the argument for technology is not real, because the technology that is said to be transferred is usually obsolete or outdated technology.

Point before it was ATM machine is a case in imported to the development of states the activities of the MNCs particularly those in the oil and gas sector have constitute a major threat to the environment of the host countries. Oil spillage pollutes streams, arable economic land crops and even air. There is also gas flaring which has serious health consequences on the inhabitants. A typical example is the current situation in the Niger-Delta region of Nigeria.

The repatriation of salaries and profits is another argument against the activities of MNCs. MNCs are found of plunging back the profit they made from the host country to their parent country.

MNCs are said to be indifferent to local economic development. They hardly re-invest salaries and profits in host countries; instead, they are in the attitude of draining scarce financial resources of host countries to further their economic interest. MNCs are referred to as agents of capital flight. They hardly support in significant way local economic development. For instance, shell plc, started drilling oil in Nigeria since 1937 but establishing only a programme of assistance in 1980 after 43 years of acute exploitation of Nigeria resources.

The MNCs engage in over-invoice of imported capital goods and under-invoice export raw materials. Thus, MNCs make highly 
abnormal, super fits on their host countries because of sharp business malpractice.

MNCs are found with the habit of intervening in the politics of host countries. For instance, Chilean government under El Salvador in 1973 was overthrown and of Gen. Murtala Mohammed regime in 1976. They have also involved in similar tendencies in Nicaragua, Cuba, Haiti; Libya, Iraq and Panama. MNCs are also ready instruments of parent countries to achieve any desired political and economic goals.

The activities of MNCs are shrouded in secrecy. This explains their willingness to disclose or declare the profits made annually to host countries. Consequently it is difficult to allocate appropriate value of tax that commensurate with their income. This is even more difficult in developing countries since they have weak bureaucracies to effectively monitor and control the MNCs.

\section{Conclusion}

The Study of MNCs/FDI is both fascinating an important for understanding economic globalization. The paper has highlighted the controversial role of MNCs in the international system, indeed their role whether benevolent or otherwise is exaggerated by both the proponents and opponents alike. The fact is the activities of the MNCs in countries with indigenous technology and political will have proven to be a blessing to host counties, while countries with monoculture economy and technological backwardness like Nigeria, sees MNCs as agents of imperialism and exploitation. The paper also noted that what so ever may be the case' MNCs are an integral part of modern regionalization and globalization. Even though it is evident that no country in the contemporary world can be devoid of FDI. The paper concludes that the less Develop countries should diversify massively to Agriculture and other sources as an alternative to oil and other monoculture source. This is in addition to high level of exportation to international markets. Also the role of MNCs and FDI should be in line with the less developed home grown policies, and not a policies from without, with full fledge political 'will'. In the part of the host countries least of the above suggestions, the issue raised will remain un-resolve.

\section{References}

1. Aja AA (2001) International Economic Relations Data Bloble Nigeria, Oweri.

2. Spero JE (1978) The Politics of International Economic Relations, St. Martins Press, New York.

3. Eldridge GJ (2003) What is Multinational Corporations. Encyclopedia of Management.

4. Widstrand C (1975) Multinational Firm in Africa offset Centre, Uppsala.

5. Eze O (1984) Human rights in Africa. Some selected problem, NIIA, Lagos.

6. Enmuo A (1999) Elements of Politics, Malthouse Press, Lagos.

7. Offiong DA (1980) Imperialism and Dependency, Fourth Dimension Pulishing Company, Enugu. 